EXERCíCIOS POÉTICOS 


\section{Tudo e o tempo}

Sergio Alves Peixoto

Universidade Federal de Minas Gerais

Um cavalo corta o campo com seus passos de veludo.

Corta o canto do meu verso com seu absconso coturno.

Corta a cor do teu sorriso que me assombra a cada novo

galopar terso e preclaro de teus dedos no meu corpo.

Corta e recorta meus sonhos povoados por teus pêlos.

Corta e acalanta meu sexo com sua crina de desejos.

Corta e reinventa o menino que dorme a teu lado e sonha.

Corta e confere o seu cheiro de espanto e de esperma.

Corta e desenha uns olhos belos, como aquela forma inteiriça e cálida: a de um ovo na sua ovalada inteireza.

Corta, corta, corta, corta a vida que se condensa 
nas dobras da pele antiga

- palimpsesto do tempo.

Um cavalo corta o campo

E me corta a alma ao meio. 